\title{
Red Mud-Blast Furnace Slag-Based Alkali-Activated Materials
}

\author{
Alessio Occhicone ${ }^{1, *}$, Mira Vukčević ${ }^{2}$, Ivana Bosković ${ }^{2}$ (D) and Claudio Ferone ${ }^{1}$ (D) \\ 1 Department of Engineering, University of Naples 'Parthenope', Centro Direzionale, Isola C4, \\ 80143 Napoli, Italy; claudio.ferone@uniparthenope.it \\ 2 Faculty of Metallurgy and Technology, University of Montenegro, Džordža Vašingtona bb, \\ 81000 Podgorica, Montenegro; mirav@ucg.ac.me (M.V.); ivabo@ac.me (I.B.) \\ * Correspondence: alessio.occhicone001@studenti.uniparthenope.it; Tel.: +39-3284881506
}

Citation: Occhicone, A.; Vukčević,

M.; Bosković, I.; Ferone, C. Red

Mud-Blast Furnace Slag-Based

Alkali-Activated Materials.

Sustainability 2021, 13, 11298

https: / / doi.org/10.3390/

su132011298

Academic Editor: Antonio Caggiano

Received: 17 September 2021

Accepted: 8 October 2021

Published: 13 October 2021

Publisher's Note: MDPI stays neutral with regard to jurisdictional claims in published maps and institutional affiliations.

Copyright: (C) 2021 by the authors. Licensee MDPI, Basel, Switzerland. This article is an open access article distributed under the terms and conditions of the Creative Commons Attribution (CC BY) license (https:// creativecommons.org/licenses/by/ $4.0 /)$.

\begin{abstract}
The aluminum Bayer production process is widespread all over the world. One of the waste products of the Bayer process is a basic aluminosilicate bauxite residue called red mud. The aluminosilicate nature of red mud makes it suitable as a precursor for alkali-activated materials. In this work, red mud was mixed with different percentages of blast furnace slag and then activated by sodium silicate solution at different $\mathrm{SiO}_{2} / \mathrm{Na}_{2} \mathrm{O}$ ratios. Obtained samples were characterized by chemical-physical analyses and compressive strength determination. Very high values of compressive strength, up to $50 \mathrm{MPa}$, even for high percentage of red mud in the raw mixture (70 wt.\% of RM in powder mixture), were obtained. In particular, the higher compressive strength was measured for cubic samples containing $50 \mathrm{wt} . \%$ of RM, which showed a value above $70 \mathrm{MPa}$. The obtained mixtures were characterized by no or scarce environmental impact and could be used in the construction industry as an alternative to cementitious and ceramic materials.
\end{abstract}

Keywords: red mud; blast furnace slag; geopolymer-based materials

\section{Introduction}

Aluminum is one of the most used materials in the world. In fact, more than 120 billion tons are produced every year [1]. The most commonly used ore for aluminum production is bauxite, where aluminum is present as oxides and hydroxides $\left(\mathrm{AlO}(\mathrm{OH}), \mathrm{Al}(\mathrm{OH})_{3}\right)[2]$.

The composition of the bauxite varies according to the place where the deposit is located, and from the deposit itself. The most economically convenient minerals are those containing more than $45 \mathrm{wt}$ \% of aluminum oxide, about $12 \mathrm{wt}$ \% of iron oxide, and less than 8 wt. \% of $\mathrm{SiO}_{2}[2,3]$.

The Bayer process is industrially adopted all over the world where aluminum is obtained from the electrolysis of molten aluminum salts. The key technological step in the Bayer process is the leaching of bauxite with concentrated $\mathrm{NaOH}$ at high temperatures (up to $250{ }^{\circ} \mathrm{C}$ ), which causes the formation of aluminate ions $\left[\mathrm{Al}(\mathrm{OH})_{4}\right]^{-}$, from gibbsite $\left(\mathrm{Al}(\mathrm{OH})_{3}\right)$ and boehmite $(\mathrm{AlO}(\mathrm{OH}))$ [4]. The leaching products are sodium aluminate solution and a residue called red mud (RM). The latter is mainly composed of iron oxides, quartz, sodium aluminosilicates, calcium carbonate, aluminate, titanium dioxide, and traces of other metallic oxides [5,6]. Once the RM is separated from the sodium aluminate solution, it is stored in open ponds in the form of liquid-solid suspension.

The production of one ton of aluminum generates between 0.9-2 tons of residue, depending on the initial composition of bauxite [7]. The difficulties in managing this residue are related to both the high volume generated and the high alkalinity of this material [8].

Currently, 27 countries produce more than 200 thousand tons of RM per year [9] and, considering the quantity produced through the years in other 50 dismissed sites, the total amount of RM currently stored exceeds 3 Gtonnes [10]. Moreover, the annual production of RM is constantly growing, associated with the constant increase of aluminum request. 
Consequently, the continuous increase in the amount of RM produced represents a very serious environmental problem [11]. Since the 1970s, the problem of managing this waste has been clear. At that time, only two disposal methods were used: discharge into the sea and lagooning.

The first is certainly the simplest to implement, since the residue, coming from the washing process, is directly spilled into the sea through a pipe placed at a due distance from the coast [12]. However, the RM thus treated tends to deposit on the seabed with a considerable impact on the whole aquatic life, due to the high basicity and ionic charge [4]. The unavoidable effects of this process are the high release of toxic substances, the increase in turbidity and the formation of magnesium and aluminum colloidal compounds in seawater [12]. The majority of the plants currently in operation have stopped disposing of bauxite residues in this way [13].

Most of the waste generated by the Bayer process is disposed of in huge terrestrial basins (artificial or natural), whose bottom should be waterproofed to avoid leakage. Several accidents such as those in China and Hungary are evident proof of the catastrophic environmental potential of RM [10,14].

Even today the disposal of RM is the main problem of any alumina/aluminum manufacturing industry. In the last years, new systems have been developed for residue management, in particular, based on the reduction of waste basicity and its complete neutralization [13-15].

The need to produce a residue with an even lower residual soda level pushed for a progressive recovery improvement, which is now near 96\% [16]. The first separation instruments such as Kelly filters and multi-chamber washers have given way to super thickeners, deep cone washers, vacuum disc filters, vacuum drum filters, and frame filters. Thus, the solids content of the residue produced has risen from about $20 \%$ of lagooning disposal to about 77\% [17]. Simultaneously, many possible applications have been developed for the reuse of neutralized RM: construction, adsorbent of organic compounds, or industrial catalysts are just a few examples. Currently, bauxite residue is used mainly as a road filler, in addition to other powdered materials such as blast furnace slag (BFS) and cement [18]. In fact, the construction of new roads should employ huge amounts of this product, as demonstrated in the construction of the Perth-Bunbury highway (west coast of Australia) [19].

Considering the large amount of material disposed of, various research areas have been opened, considering the economic and environmental factors. One of the most promising is their use in the construction industry. In particular, in this field, a lot of papers have been published about the use of neutralized bauxite residues as an additive in Portland cement $[20,21]$. RM has also been used, together with Portland cement and silica, as a component for lightweight components, used as insulators, fire-resistant elements, and for precast building, in particular in areas with high seismic risk [22].

Numerous recent studies have investigated the use of wastes as precursors of alkaliactivated materials $[23,24]$. The low percentage of silica and alumina in its composition makes RM unsuitable as the sole precursor, so other aluminosilicates must be added [25], but its intrinsic alkalinity promotes the activation. These materials have characteristics comparable to cement-based hydraulic binders; in fact, they present good compressive strength, good resistance to aggressive environments and could be used as thermal storage materials [26], lightweight at low environmental impact [27-29] catalyst support or as adsorbent material [30].

In this work, new mixture compositions, as well as a curing schedule for the use of net bauxite residue as a co-precursor in the production of alkali-activated materials, were studied. Pastes were obtained by combining the RM with blast furnace slag (BFS) activated by sodium silicate (SS) solution at various $\mathrm{SiO}_{2} / \mathrm{NaO}_{2}(\mathrm{R})$ ratios and cured at different temperatures. 


\section{Materials and Methods}

\subsection{Selection and Characterization of the Raw Materials}

Red mud (RM) originated from the aluminum metallurgical plant in Podgorica, Montenegro was dried to constant mass at a temperature of $105^{\circ} \mathrm{C}$, and then ground in a ball mill. The milling process created a powder with bimodal size distribution with a first maximum around $7 \mu \mathrm{m}$ and the second around $150 \mu \mathrm{m}$. In particular, it turned out that the $D_{10}$ was $3.5 \mu \mathrm{m}$, the $\mathrm{D}_{50}$ was $30 \mu \mathrm{m}$, and the $\mathrm{D}_{90}$ was $185 \mu \mathrm{m}$.

Granulated BFS was supplied by ECOCEM, France, while SS $\left(\mathrm{R}=\mathrm{SiO}_{2}: \mathrm{Na}_{2} \mathrm{O}=3.4\right.$, $\mathrm{Na}_{2} \mathrm{O}$ 7.5-8.5 wt.\%, $\mathrm{SiO}_{2} 25.5-28.5$ wt. $\%$ and $\rho=1.347 \mathrm{~g} / \mathrm{cm}^{3}$ ) was supplied by Prochin Italia S.r.l. The $\mathrm{R}$ ratio of the activating solution was modified by adding anhydrous pellets of the reagent sodium hydroxide (Sigma Aldrich) with a grade of purity $>98 \%, 24 \mathrm{~h}$ before the preparation of samples.

Recent studies demonstrated that energy dispersive X-ray spectroscopy analysis (EDS) large area mapping can be successfully applied to obtain the chemical characterization of amorphous and crystalline phases [31]. The chemical composition of used materials was measured by EDS analysis, according to the following procedure: powder samples to be analyzed were ground to $<100 \mu \mathrm{m}$ size, homogenized, and pressed to form a disk of $\approx 1 \mathrm{~cm}$ diameter. The obtained disk was analyzed by EDS without metallization and for all samples, an area of about $1 \mathrm{~mm}^{2}$ was selected for the EDS analysis. The analysis was performed on five different areas with the same dimensions for each sample. Results reported in Table 1 are the average of five measurements of EDS analysis performed on the selected area for all analyzed powder fractions.

Table 1. Chemical composition of RM, BFS expressed as weight percentage of oxides from EDS analysis. Average of 5 different $1 \mathrm{~mm}^{2}$ areas.

\begin{tabular}{ccccccccc}
\hline \multicolumn{7}{c}{ Oxides (\%) } \\
\hline Material & $\mathrm{SiO}_{\mathbf{2}}$ & $\mathbf{A l}_{\mathbf{2}} \mathbf{O}_{\mathbf{3}}$ & $\mathbf{N a}_{\mathbf{2}} \mathbf{O}$ & $\mathbf{F e}_{\mathbf{2}} \mathbf{O}_{\mathbf{3}}$ & $\mathbf{T i O}_{\mathbf{2}}$ & $\mathbf{M g O}$ & $\mathbf{C a O}$ & $\mathbf{K}_{\mathbf{2}} \mathbf{O}$ \\
\hline $\mathrm{RM}$ & $15.5 \pm 0.1$ & $24.0 \pm 0.4$ & $8.1 \pm 0.1$ & $45.0 \pm 0.2$ & $5.4 \pm 0.1$ & $0.9 \pm 0.1$ & $0.8 \pm 0.1$ & $0.30 \pm 0.05$ \\
$\mathrm{BFS}$ & $35.7 \pm 0.7$ & $11.2 \pm 0.1$ & In trace & $0.3 \pm 0.1$ & $0.5 \pm 0.1$ & $6.5 \pm 0.1$ & $43.9 \pm 0.8$ & $0.31 \pm 0.07$ \\
\hline
\end{tabular}

\subsection{Samples Characterisation}

Wide-angle X-ray diffraction patterns were obtained at room temperature with an automatic Rigaku powder diffractometer Miniflex 600 (Tokyo, Japan) operating in the $\theta / 2 \theta$ Bragg-Brentano geometry and using $\mathrm{CuK} \alpha$ radiation $(\lambda=1.54 \AA, 40 \mathrm{kV}, 15 \mathrm{~mA}, 2 \theta$ range from 5 to $80^{\circ}$, step size $0.020^{\circ} 2 \theta, 0.5$ slit width). The phase recognition was carried out by using the PDF-4+ 2020 database (International Centre for Diffraction Data ${ }^{\circledR}$, Newtown Square, PA, USA) and the Rigaku PDXL2 software (Rigaku, Tokyo, Japan).

Particles size distribution data values were obtained with Mastersizer 3000 laser diffraction particle size analyzer.

Scanning electron microscopy (SEM) microstructural analysis was performed by using a Phenom Pro X Microscope on freshly prepared fractured surfaces. The same instrument has been used for energy-dispersive X-ray spectroscopy (EDS) analysis.

Thermogravimetric analyses were performed with a Mettler Toledo TGA/DSC 2 STAR ${ }^{\mathrm{e}}$, with a heating rate of $10^{\circ} \mathrm{C} / \mathrm{min}$ from 25 to $1000{ }^{\circ} \mathrm{C}$ in air flow.

The FTIR absorption spectra were recorded in the range of $4000-400 \mathrm{~cm}^{-1}$ using a Nicolet system, model Nexus, equipped with a DTGS KBr detector (deuterated triglycine sulphate with potassium bromide windows). A spectral resolution of $2 \mathrm{~cm}^{-1}$ was chosen.

Mechanical sample analysis was performed with Controls MCC 8 hydraulic console with $2000 \mathrm{kN}$ capacity at the velocity of $1200 \mathrm{~N} / \mathrm{s}$. The procedure was adapted from (UNI EN 196-1:2016). 


\subsection{Preparation of the Samples}

Based on the wide authors' experience on the preparation of alkali-activated mixes $[26,27,29,32,33]$, a procedure was chosen which consisted in adding small quantities of RM powder to the alkaline activated solution under constant mixing. After the addition of RM, BFS powder was slowly added under $500 \mathrm{rpm}$ frequency stirring. The RM particles reacted more slowly than the BFS ones, so adding both powders at the same time, or adding first the BFS, would make it difficult to correctly mix the sample. Similar behavior occurred when liquid was added to the powder mix and not vice versa. This approach was adopted to avoid the agglomration of the powders and therefore the formation of aggregates with poor physical properties. Ten mixtures and two curing schedules were prepared. The composition of each mixture is given in Table 2.

Table 2. RM-BFS mixtures' composition.

\begin{tabular}{|c|c|c|c|c|c|}
\hline Name & RM (\%) & BFS (\%) & Solid/Liquid & $\mathrm{R}\left(\mathrm{SiO}_{2} / \mathrm{NaO}_{2}\right)$ & Curing Temperature $\left({ }^{\circ} \mathrm{C}\right)$ \\
\hline RM50_1.2_RT & 50 & 50 & 2.22 & 1.2 & 25 \\
\hline RM50_1.2_60 & 50 & 50 & 2.22 & 1.2 & 60 \\
\hline RM50_1.6_RT & 50 & 50 & 2.22 & 1.6 & 25 \\
\hline RM50_1.6_60 & 50 & 50 & 2.22 & 1.6 & 60 \\
\hline RM50_2_RT & 50 & 50 & 2.22 & 2 & 25 \\
\hline RM50_2_60 & 50 & 50 & 2.22 & 2 & 60 \\
\hline RM50_2.4_RT & 50 & 50 & 2.22 & 2.4 & 25 \\
\hline RM50_2.4_60 & 50 & 50 & 2.22 & 2.4 & 60 \\
\hline RM50_2.8_RT & 50 & 50 & 2.22 & 2.8 & 25 \\
\hline RM50_2.8_60 & 50 & 50 & 2.22 & 2.8 & 60 \\
\hline RM0_2_RT & 0 & 100 & 2.22 & 2 & 25 \\
\hline RM0_2_60 & 0 & 100 & 2.22 & 2 & 60 \\
\hline RM30_2_RT & 30 & 70 & 2.22 & 2 & 25 \\
\hline RM30_2_60 & 30 & 70 & 2.22 & 2 & 60 \\
\hline RM70_2_RT & 70 & 30 & 2.22 & 2 & 25 \\
\hline RM70_2_60 & 70 & 30 & 2.22 & 2 & 60 \\
\hline RM80_2_RT & 80 & 20 & 2.22 & 2 & 25 \\
\hline RM80_2_60 & 80 & 20 & 2.22 & 2 & 60 \\
\hline RM100_2_RT & 100 & 0 & 2.22 & 2 & 25 \\
\hline RM100_2_60 & 100 & 0 & 2.22 & 2 & 60 \\
\hline
\end{tabular}

The pastes were molded in cylindrical molds of $\approx 27 \mathrm{~mm}$ in diameter and $\approx 50 \mathrm{~mm}$ in height. Two different curing conditions were implemented: (i) at room temperature (RT) with $95 \%$ of humidity for $7 \mathrm{~d}$, and further $21 \mathrm{~d}$ at room temperature and humidity; (ii) at $60{ }^{\circ} \mathrm{C}$ with $95 \%$ of humidity in oven for $24 \mathrm{~h}, 6 \mathrm{~d}$ at room temperature and $95 \%$ of humidity, and a further $21 \mathrm{~d}$ at room temperature and humidity.

The pastes with 30,50, and 70\%wt of RM in powder mixture were also molded in a cubic $40 \mathrm{~mm}$ side mold, to make a comparison with literature references. These samples were characterized only under compression strength point of view and compared with the corresponding cylindrical samples.

\section{Results}

\subsection{SEM/EDS Analysis}

SEM-EDS analysis with BSE (back scattered electrons) images was performed. It was possible to observe areas with different contrast in Figure 1. This is likely due to BSE images provided by the instrument. In fact, in this kind of analysis, differences in brightness depend on heavier or lighter atoms. Analyzing the images with the EDS combined instrument it was possible to confirm that some of these particles have a composition rich in aluminum or ferrous oxides that could be ascribed to unreacted RM particles. 


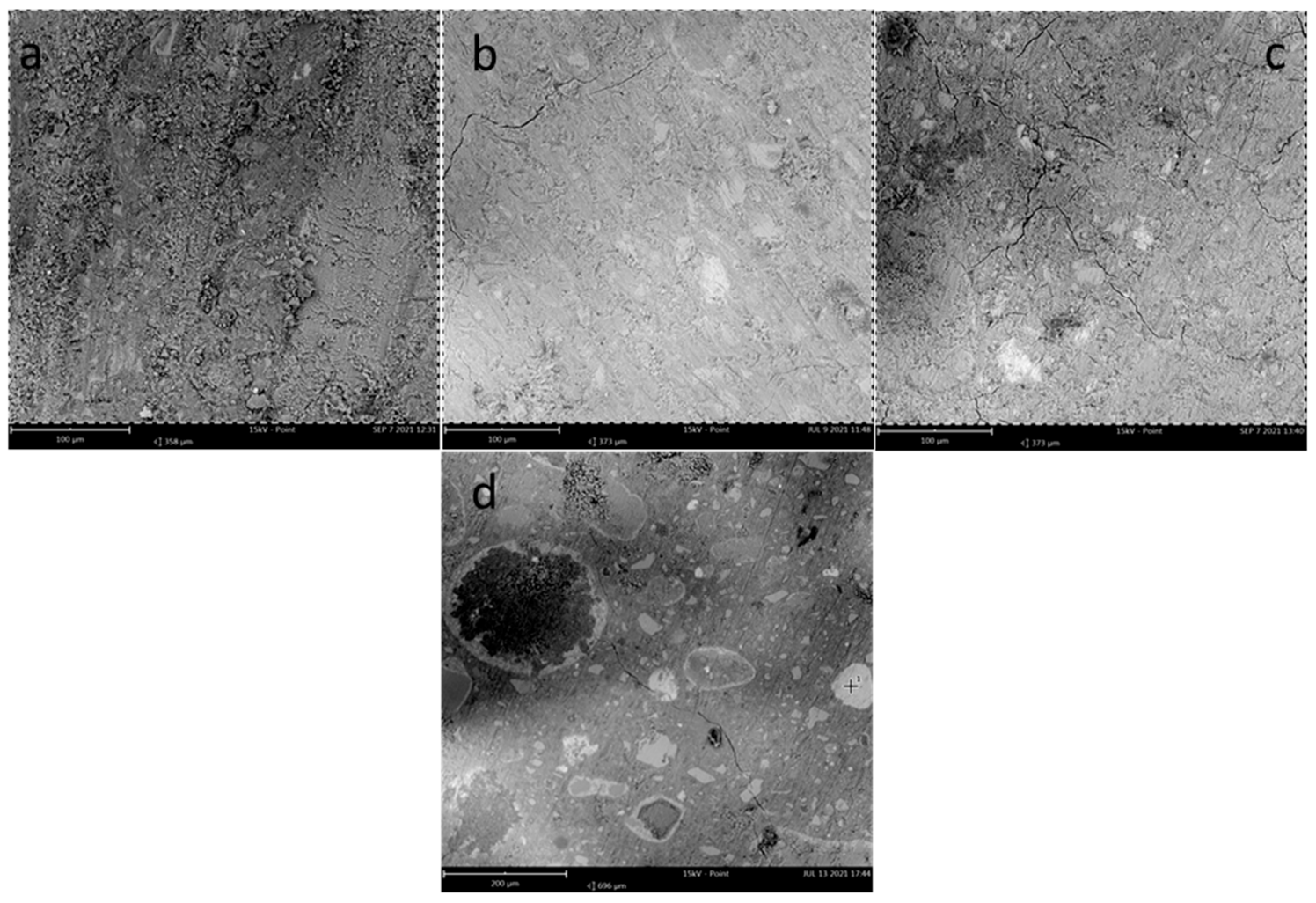

Figure 1. SEM images indicating the areas of EDS analysis in RM30_2_RT (a) RM50_2_RT (b) RM70_2_RT (c) samples. The analysis was performed on each region area $(\mathbf{a}-\mathbf{c})$ and one spot $(\mathbf{d})$.

For the sample with $50 \mathrm{wt} . \%$ of RM in the powder mixture, the average composition was about $34 \mathrm{wt} . \%$ of silicon oxide (mainly due to SS use and silicon oxide present in BFS and, in part, from RM), $21 \mathrm{wt} . \%$ of calcium oxide, and $9 \mathrm{wt} . \%$ of iron oxide (all the results are shown in Table 3).

Table 3. RM-BFS oxides mixtures weight percentage. The first three lines are related to the average of 5 different $1 \mathrm{~mm}^{2}$ areas, while the last one is the spot reported in Figure 1d.

\begin{tabular}{ccccccccc}
\hline Material & $\mathbf{C}$ & $\mathbf{C a O}$ & $\mathbf{S i O}_{\mathbf{2}}$ & $\mathbf{F e}_{\mathbf{2}} \mathbf{O}_{3}$ & $\mathbf{N a}_{\mathbf{2}} \mathbf{O}$ & $\mathbf{A l}_{\mathbf{2}} \mathbf{O}_{\mathbf{3}}$ & $\mathbf{M g O}$ & $\mathbf{T i O}$ \\
\hline RM30_2_RT & $13.9 \pm 1.1$ & $22 \pm 2$ & $33 \pm 2$ & $5.2 \pm 1.0$ & $8.5 \pm 0.7$ & $10.2 \pm 1.2$ & $4.1 \pm 0.8$ & $0.86 \pm 0.15$ \\
RM50_2_RT & $15.0 \pm 1.2$ & $20.5 \pm 1.1$ & $34 \pm 2$ & $8.8 \pm 0.9$ & $8.1 \pm 0.9$ & $10.5 \pm 1.7$ & $3.4 \pm 0.4$ & $0.92 \pm 0.18$ \\
RM70_2_RT & $16.5 \pm 1.3$ & $20.2 \pm 1.5$ & $28 \pm 2$ & $11.1 \pm 1.2$ & $8.3 \pm 0.6$ & $11.1 \pm 1.5$ & $2.7 \pm 0.7$ & $1.26 \pm 0.13$ \\
RM50_2_RT(spot) & 3.52 & 6.46 & 14.25 & 58.05 & 3.4 & 5.35 & 1.19 & 7.78 \\
\hline
\end{tabular}

The EDS analysis results reflected the different compositions of the raw precursors. In particular, the Fe content increased with the RM wt.\% and Ca increased with BFS wt.\%. The three SEM images revealed the presence of a compact structure in all the samples, characterized by a matrix incorporating several particles with good adhesion between them. According to a spot analysis performed on a particle in Figure $1 \mathrm{~d}$ and reported in Table 3, it was possible to observe that it was particularly rich in Fe and consequently it could likely be ascribed to unreacted RM. On the other hand, silicon, aluminum, and calcium oxides were mostly present in the matrix. This matrix was likely composed of the amorphous phase resulting from alkaline activation, as confirmed by XRD analysis.

Furthermore, $\mathrm{Si} / \mathrm{Al}$ 2:1 ratio represented the best condition for geopolymerization (poly(sialate-siloxo)) [34]. Therefore, under these conditions, it was possible to create a hybrid structure formed by $\mathrm{C}(\mathrm{A}) \mathrm{SH}$ and geopolymer domains, whose growth was probably limited by the quicker formation of the hydrated calcium aluminosilicate phase. A complete 
representation of the structure is viewable in Figure 2 (obtained by the mapping function of the EDS analysis software).

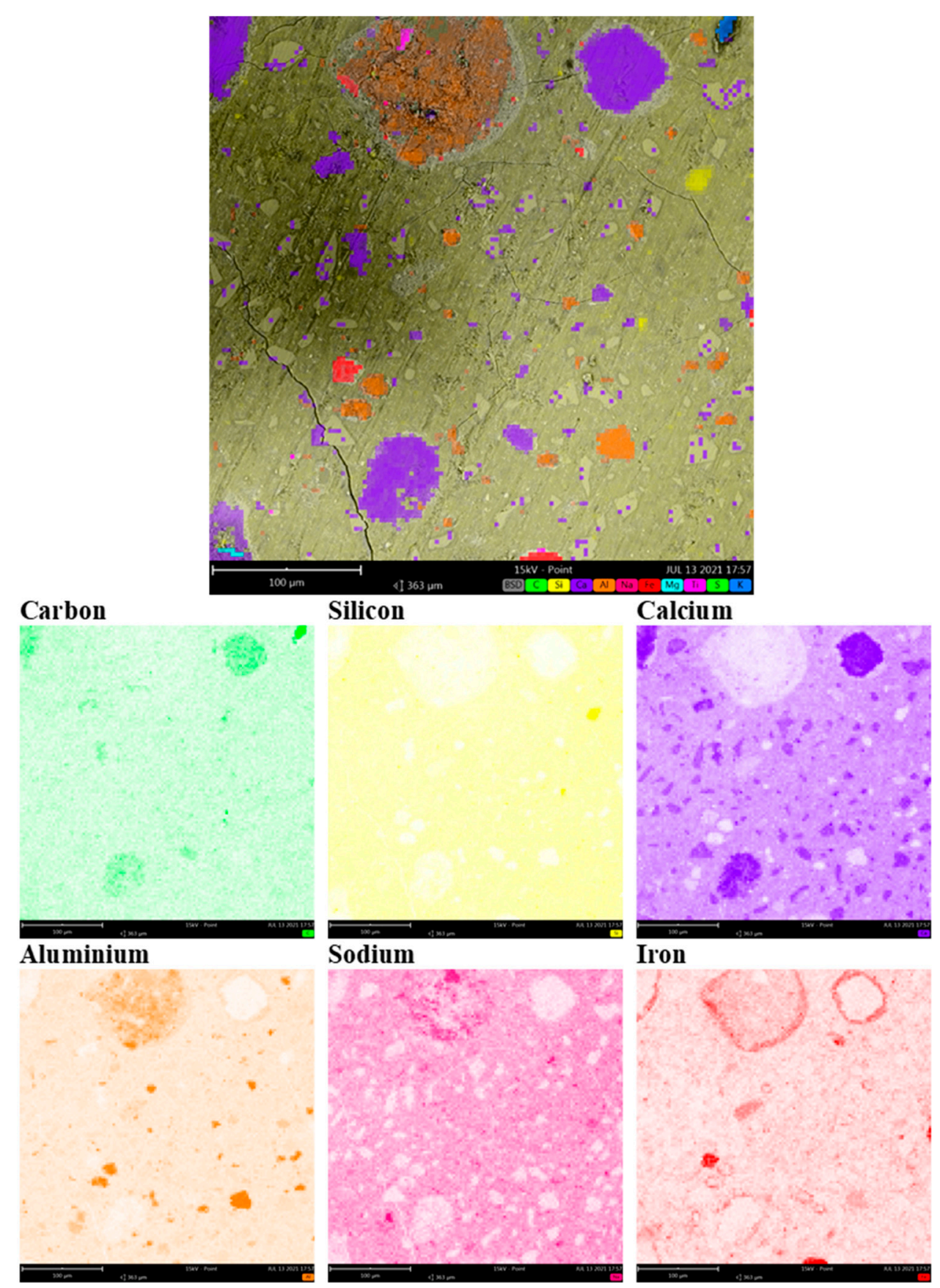

Figure 2. Completed mapping of a region of RM50_2_RT sample, with relative mapping of the main oxides.

As clearly evidenced by the elemental map, the structure was composed of a matrix containing sodium, silicon, calcium, and in part aluminum (NASH-CS(A)H), in which particles consisting of calcium carbonate, iron, aluminum, and titanium oxides were randomly distributed. This type of structure, with the presence of unreacted particles in an amorphous phase, reduced shrinkage problems by limiting the formation of cracks and micro-cracks. This microstructure was likely responsible for the high mechanical performances of these materials. 


\section{2. $T G A$}

Thermogravimetric analysis was performed on raw RM and on two different samples with the same mix design, but different curing conditions. The three curves (RM and those related to samples with different curing) showed some small differences as it is possible to observe in Figure 3.

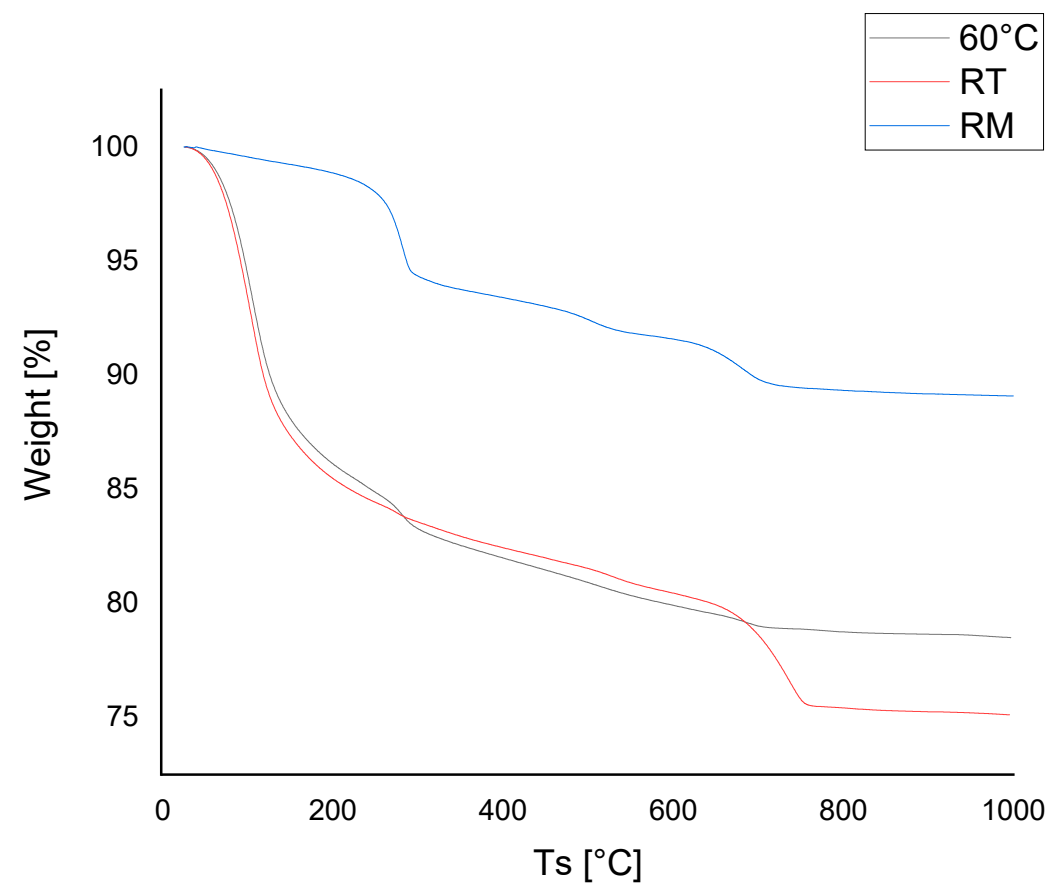

Figure 3. TGA analysis (red) RM50_2_RT; (black) RM50_2_60, (blue) dried RM.

1. The curing conditions did not significantly affect the behavior of the final product. In fact, the amount of water in the samples after 28 days was almost the same. In both cases, a weight loss of 14 to $15 \mathrm{wt} . \%$ (appreciable from the curves in the temperature range $25-220^{\circ} \mathrm{C}$ ) due to the water still present in the sample, with an inflection point around $105^{\circ} \mathrm{C}$, was observed;

2. A second weight loss of approximately $2 \mathrm{wt} . \%$ was recorded in the temperature range 220-400 ${ }^{\circ} \mathrm{C}$, centered at $283^{\circ} \mathrm{C}$, which could be attributed to the loss of crystallization water of the hydroxides. In this range of temperature goethite and gibbsite (see XRD pattern) can lose water to transform into hematite $[35,36]$ and boehmite, respectively, as occurred also in dried RM sample;

3. Further $2 \mathrm{wt} . \%$ in weight was lost in the temperature range $400-580{ }^{\circ} \mathrm{C}$, centered at $500{ }^{\circ} \mathrm{C}$ in all the samples and is likely related to the boehmite transformation into corundum $\left(\mathrm{Al}_{2} \mathrm{O}_{3}\right)$ [37];

4. A significant difference between the two mixtures was due to a different percentage of carbonate species. A marked weight loss in the temperature range $600-800^{\circ} \mathrm{C}$, typical of calcination (inflection point at $735^{\circ} \mathrm{C}$ ), was observed in the sample cured at RT. This phenomenon was related to the presence of calcium/sodium hydroxides in excess which carbonate during the curing and drying period, reacting with atmospheric $\mathrm{CO}_{2}$. The sample cured at the higher temperature showed a lower carbonate amount compared to the RT treated sample. This suggested that in the sample cured at $60{ }^{\circ} \mathrm{C}$ the alkali-activation reaction involved a higher amount of hydroxides, creating a higher amount of amorphous phase.

\section{3. $X R D$}

In Figure 4 the XRD pattern of RM and RM50_2_RT samples are reported. 

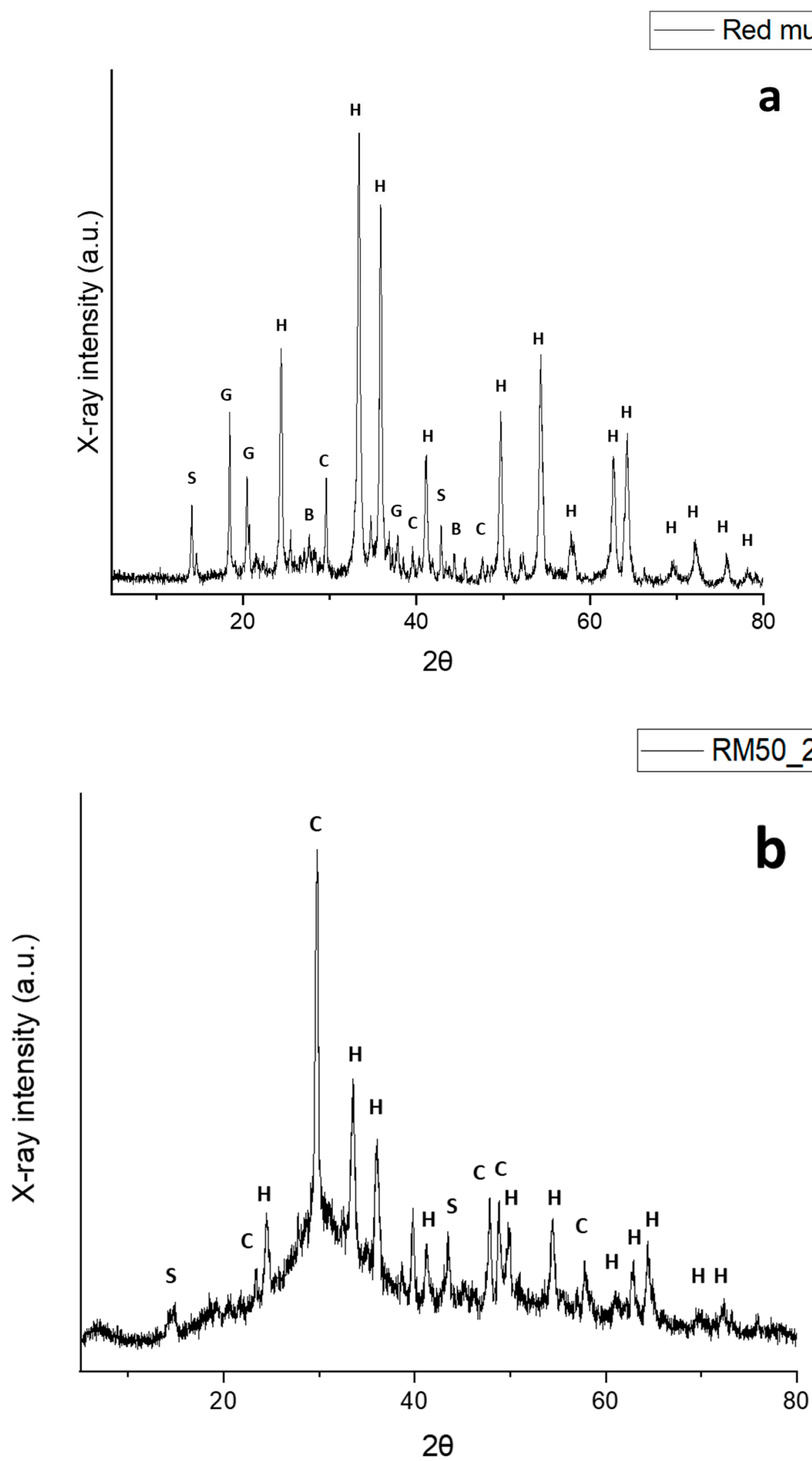

Figure 4. (a) XRD analysis of RM: H-hematite; C-calcite; S-sodalite; B-boehmite; G-gibbsite. (b) XRD analysis of RM50_2_RT: H-hematite; C-calcite; S-sodalite. 
It is possible to observe that some crystalline phases such as hematite, calcite, and sodalite, did not change their nature after the alkali activation.

As expected, no new crystalline phases could be observed, because the alkali activation was a reaction that involves and produces amorphous phases. Broad background bands are observable, which underline the presence of amorphous phases due to the interaction of SS with calcium, silicon, ferrous, and aluminum oxides. The formation of the amorphous phase was related to different parameters, such as $\mathrm{pH}$, temperature of reaction and curing, percentage of precursor in mix powder (dependence to mix powder is shown in Figure 4). We can also emphasize that the gibbsite phase was dissolved in the alkaline solution and after the reaction, it was present in the amorphous matrix. This phenomenon appears to be at the basis of geopolymers formation and presented in the amorphous phase under crystals peaks.

By the analysis of Figure 5, it is possible to underline how the amount of amorphous phase, evidenced by a broad hump between 20 and $40^{\circ} 2 \theta$, was more intense for RM50_2_RT material. In the mechanical results section, a correspondence between the amount of amorphous phase and mechanical behavior of samples was evident. In particular, the compressive strength of new materials was higher for samples with a higher amount of amorphous phase.

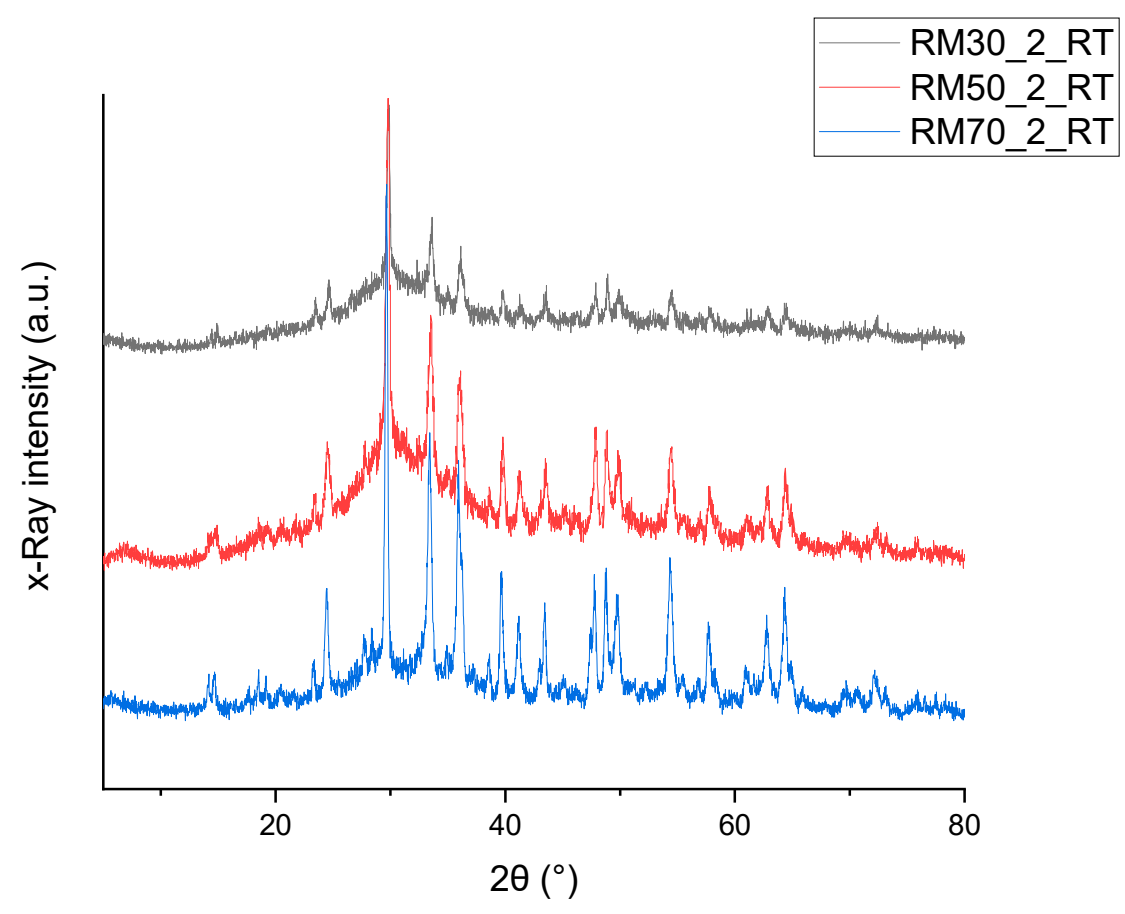

Figure 5. XRD analysis comparison among RM30_2_RT, RM50_2_RT, RM70_2_RT.

\subsection{FTIR}

The FTIR analysis showed the same behavior for samples cured at different temperatures. For this reason, only the room temperature cured spectrum was reported and compared with the RM precursor IR spectrum (Figure 6). 


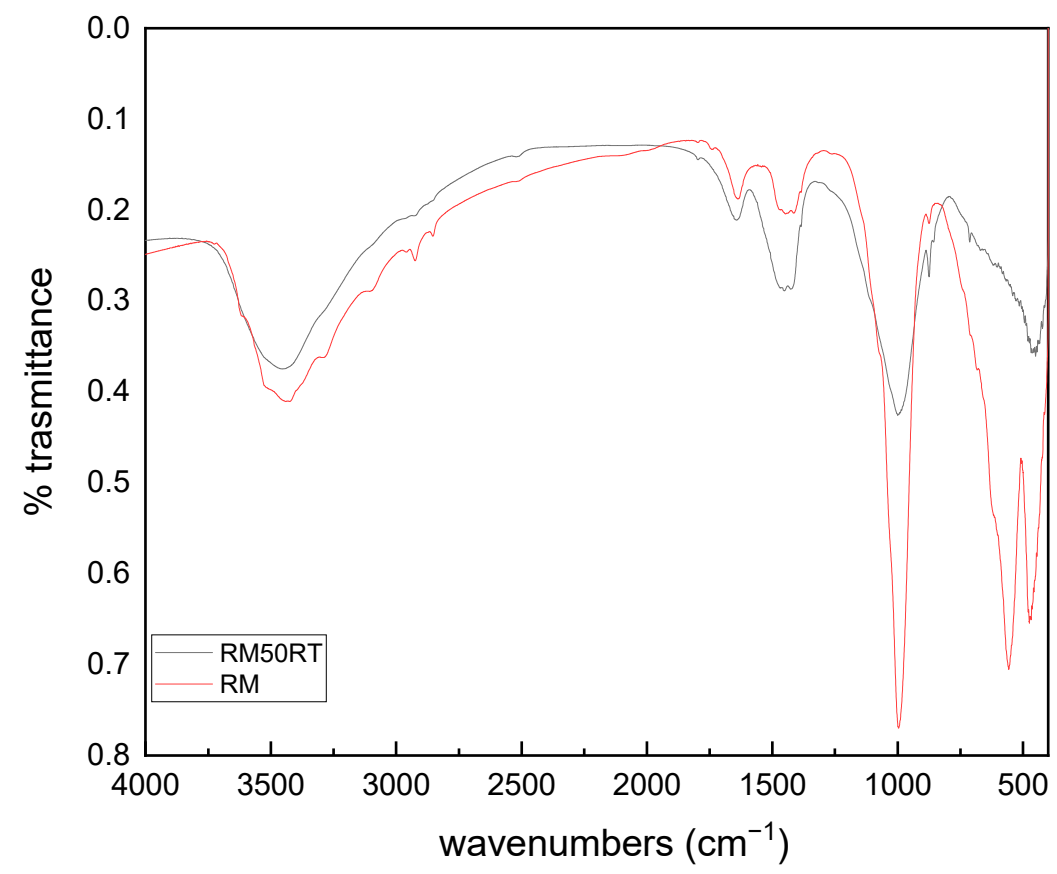

Figure 6. Red line is FTIR spectrum of RM; black line is FTIR spectrum of RM50_2_RT.

At $3450 \mathrm{~cm}^{-1}$ the bending vibrations generated by the $\mathrm{OH}$ groups in water showed similar intensity compared to the RM precursor, due to hydrate phases present in both analysed materials. The two peaks at $2900-2800 \mathrm{~cm}^{-1}$ corresponded respectively to the asymmetric and symmetric stretch of $\mathrm{CH}_{2}$ which could likely be due to the presence of a small amount of organic compound as impurity in RM [38]. At lower wavenumbers, the peak at $1635 \mathrm{~cm}^{-1}$ could be ascribed to the bending area of the bond angle $\mathrm{H}-\mathrm{O}-\mathrm{H}$, while the two peaks at 1455 and $1415 \mathrm{~cm}^{-1}$ were characteristic of the stretching $\mathrm{C}=\mathrm{O}$ due to the presence of carbonate, as also found by the XRD analysis. The characteristic bands corresponding to the $\mathrm{Si}(\mathrm{Al})-\mathrm{O}$ vibration were detected at $\sim 993 \mathrm{~cm}^{-1}$ [39], and for $\mathrm{Al}-\mathrm{OH}$ at $\sim 803 \mathrm{~cm}^{-1}$, confirming the presence of silicate and aluminum groups in RM precursor. In the alkali-activated material these peaks appeared in the first case larger but less intense and in the second one just less intense (this behavior was found also in $[34,40])$. The peaks at $\sim 560$ and $\sim 460 \mathrm{~cm}^{-1}$ present in RM were due, respectively, to the vibrations of Fe-O bonds in the tetrahedral and octahedral sites in the hematite phase. In the new material, the peak at $560 \mathrm{~cm}^{-1}$ disappeared reducing the quantity of iron in the new formulation; on the other hand, the peak visible at $460 \mathrm{~cm}^{-1}$ could be assigned to in-plane bending vibration of the $\mathrm{Si}-\mathrm{O}$, which in the $\mathrm{RM}$ spectrum was superimposed to the peak at 462 $\mathrm{cm}^{-1}$ related to octahedral $\mathrm{Fe}-\mathrm{O}$ in hematite phase [41].

\subsection{Compressive Strength}

Compressive strength values are shown in Figure 7. The two trends showed a maximum for $\mathrm{R}=2$. This behavior was probably caused by the different nature of the reactive phases:

1. The formation of $\mathrm{C}(\mathrm{A}) \mathrm{SH}$ gel, due to the BFS precursor;

2. The formation of Si-O-Al and, in less part, of Si-O-Fe phases, due to the presence of amorphous silicon and aluminum oxides in the two precursors (BFS and RM), activated by SS and sodium hydroxide [42]. 


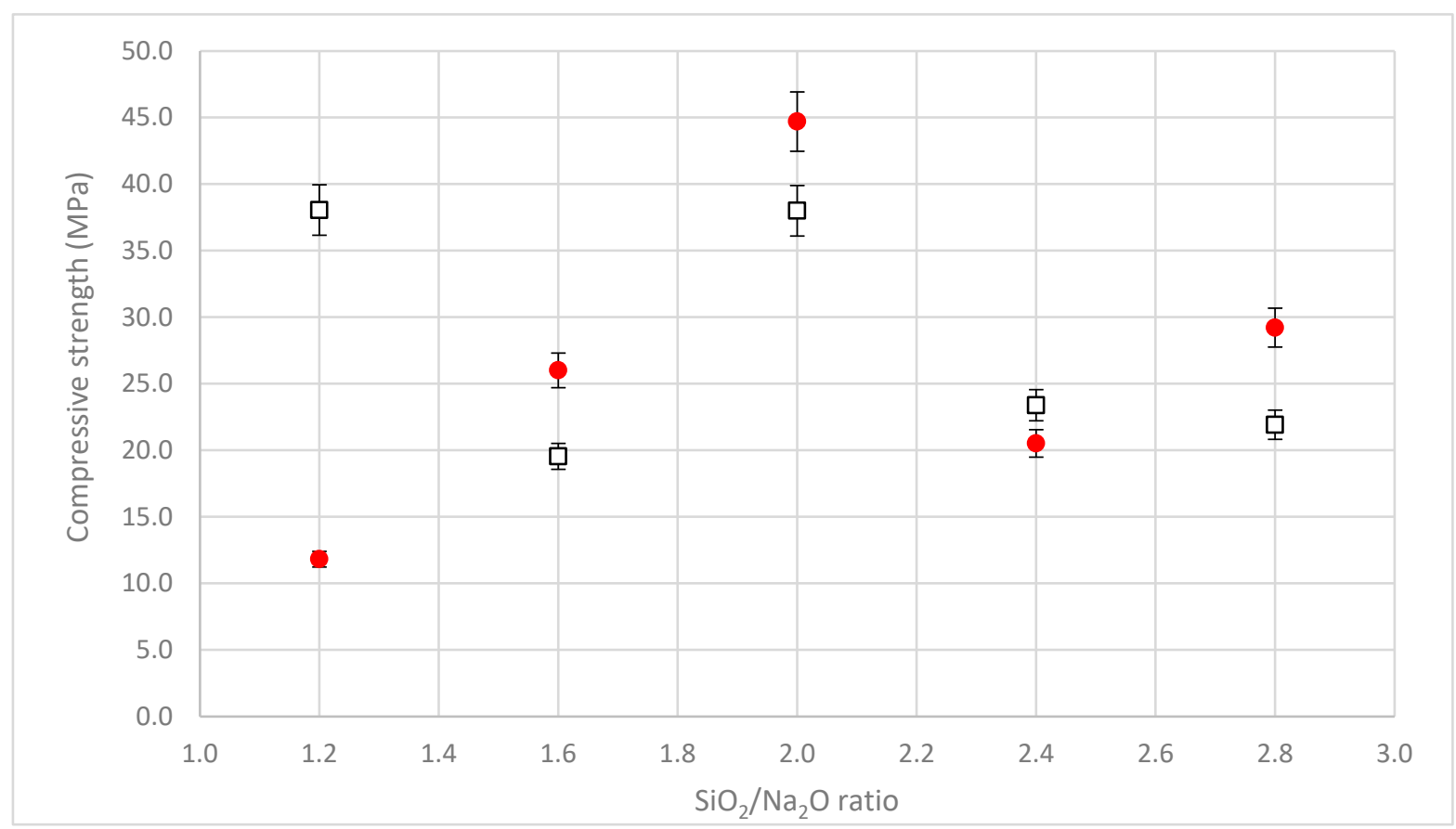

Figure 7. Compressive strength values for alkali-activated material obtained starting from RM, ground granulated BFS and alkaline solution with different $\mathrm{R}$ ratios. Hollow black squares: room temperature cured samples; red circle: samples cured at $60{ }^{\circ} \mathrm{C}$ for $24 \mathrm{~h}$.

To promote the formation of one of these phases or both, the conditions of $\mathrm{pH}$ and curing temperature played a key role. In fact, to obtain higher compressive strength it was necessary to reach optimal $\mathrm{pH}$ conditions, limiting the amount of $\mathrm{NaOH}$ in alkali activating solution. At different $\mathrm{R}$ values, it was possible to notice that:

1. With higher $\mathrm{pH}$ alkaline solution, the dissolution of silicon from the raw material and the formation of $\mathrm{CSH}$ or $\mathrm{CASH}$ gel was favored, limiting geopolymerization;

2. Decreasing the amount of $\mathrm{NaOH}$ in the activating solution, the quantity of free calcium decreased [43] and consequently, the CSH phase amount decreased, probably forming the geopolymeric $\mathrm{Si}-\mathrm{O}-\mathrm{Al}$ phase;

3. If $\mathrm{R}>2$, the low alkalinity reduced the Ca quantity in solution [43], and further decreased the solubilities of $\mathrm{Si}$ and $\mathrm{Al}[43,44]$. In these conditions, there was not enough calcium in the system to form a diffused calcium-silicate-hydrate (CSH) phase and the small amount of geopolymer gel formed [32] was responsible for mechanical strength.

For both the curing conditions there was a maximum value of strength for $\mathrm{R}=2$ and a quite similar trend for different $R$ values. Generally, the compressive strength values were very similar between the samples cured at room temperature and the ones cured at $60^{\circ} \mathrm{C}$. The only value where there was a noticeable difference was $R=1$,2. In this case, the increase of curing temperature promoted the hydration reaction rate of calcium phases from BFS. In these conditions, the reaction was so fast that the CSH phase failed to form completely. At room temperature, the reaction was slower and an amorphous phase matrix created. For the other $\mathrm{R}$ values, the reaction rate and also the evaporation of water had a different influence on the sample. Generally, these two phenomena balanced out for samples cured at different temperatures, so the final materials had similar mechanical performances.

In Figure 8, compressive strength values for alkali-activated material with different percentages of RM in the starting powder are reported. We might have expected the sample containing the greatest amount of BFS to show the greatest compressive strength. This was true at room temperature, but for the samples cured at $60^{\circ} \mathrm{C}$, the material performance decreased consistently. This phenomenon was linked to the reaction rate. In fact, at a 
higher curing temperature, the free calcium dissolved by alkaline solution rapidly reacts, preventing all the calcium atoms from dissolving and forming the amorphous matrix rich in calcium aluminosilicate. Furthermore, this behavior confirmed that at higher curing temperatures the presence of $\mathrm{RM}$ caused the formation of $\mathrm{Al}_{\mathrm{x}}-\mathrm{O}-\mathrm{Si}_{\mathrm{y}}-\mathrm{O}-\mathrm{Fe}_{\mathrm{z}}$ phases [34] different from the calcium aluminosilicate ones, which contributed significantly to the mechanical resistance of the material.

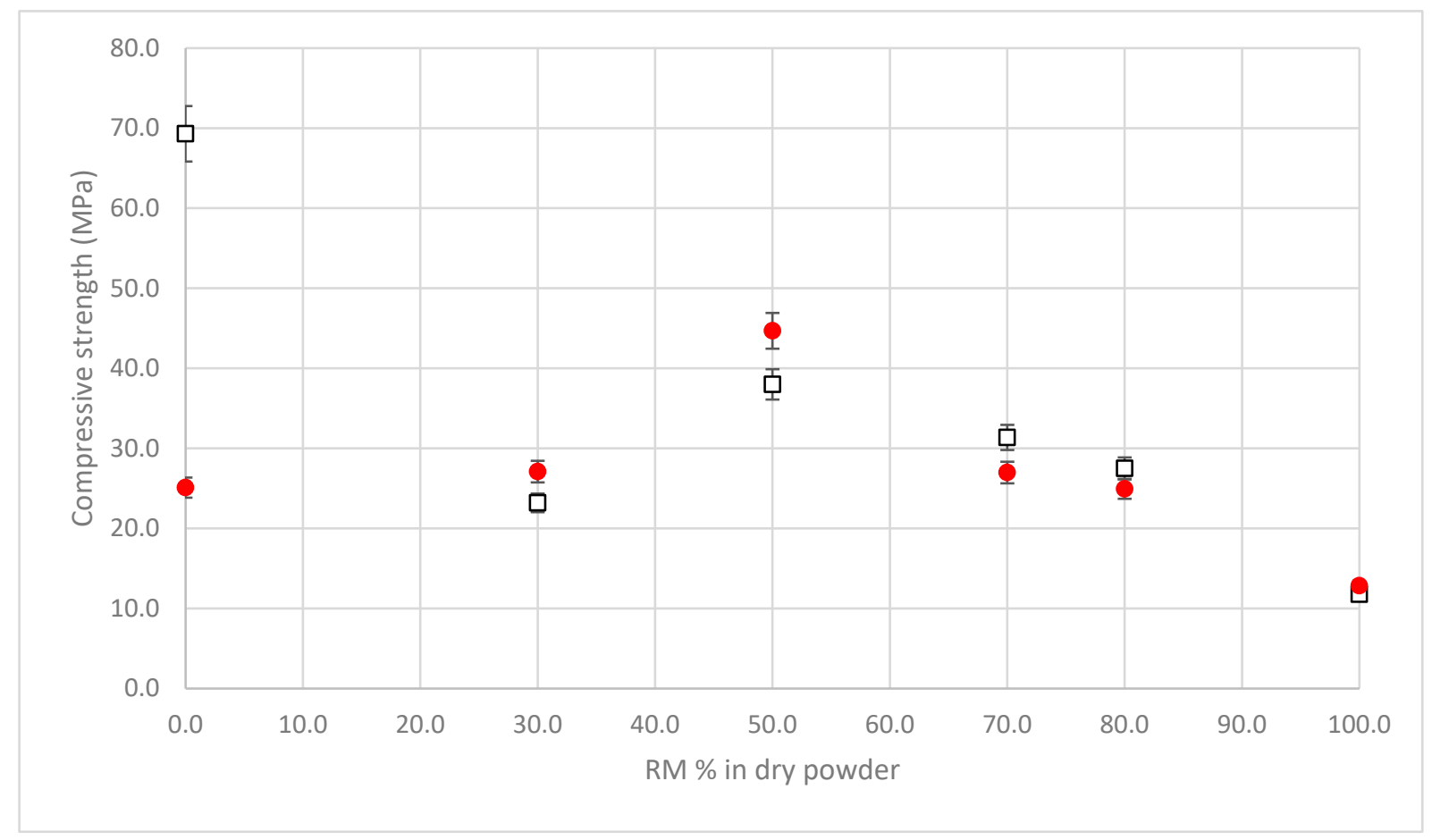

Figure 8. Compressive strength values for alkali-activated material obtained starting from RM, BFS, and alkaline solution with $\mathrm{R}=2$ and different percentages of RM in powder mix (0-100 wt.\%). Hollow black squares: room temperature-cured samples; red circle: samples cured at $60{ }^{\circ} \mathrm{C}$ for $24 \mathrm{~h}$.

It should also be emphasized that the specimens rich in RM showed interesting compressive strength values, which were, in some cases, higher than those obtained by BFS rich specimens. However, it is quite important to underline that, without BFS, the compressive strength results decreased to $12 \mathrm{MPa}$ (RM100_2_RT and RM100_2_60), against the $25 \mathrm{MPa}$ obtained with $20 \mathrm{wt} . \%$ of BFS in the powder mixture.

In general, the highest compressive stress values were recorded for a 1 to 1 ratio of $\mathrm{RM}$ and BFS, for both room temperature and $60^{\circ} \mathrm{C}$ cured samples. Similar behavior was obtained using 40-mm side cubic specimens as it is possible to see in Figure 9.

Regarding the curing temperature, our samples behaved differently compared to what usually happens for geopolymers. In fact, the compressive strength values of these new materials were better when the material was cured at room temperature compared to the tests conducted at $60^{\circ} \mathrm{C}$. This was due to the type of reactions that BFS mainly carries out with SS. In fact, BFS was activated in conditions of proper alkalinity to form a hydrated calcium silicate matrix that prevented the formation of three-dimensional structures with $\mathrm{Si}-\mathrm{O}$ and $\mathrm{Al}-\mathrm{O}$ bonds, which characterize the geopolymers. The formation of an amorphous matrix, which incorporated unreacted crystalline phases, created a compact material free of evident fracture lines, due to shrinkage phenomena, as evidenced by SEM observations. These samples were characterized by mechanical strength values similar to those of the cementitious counterparts (the amorphous and crystal phases are visible in XRD analysis). 


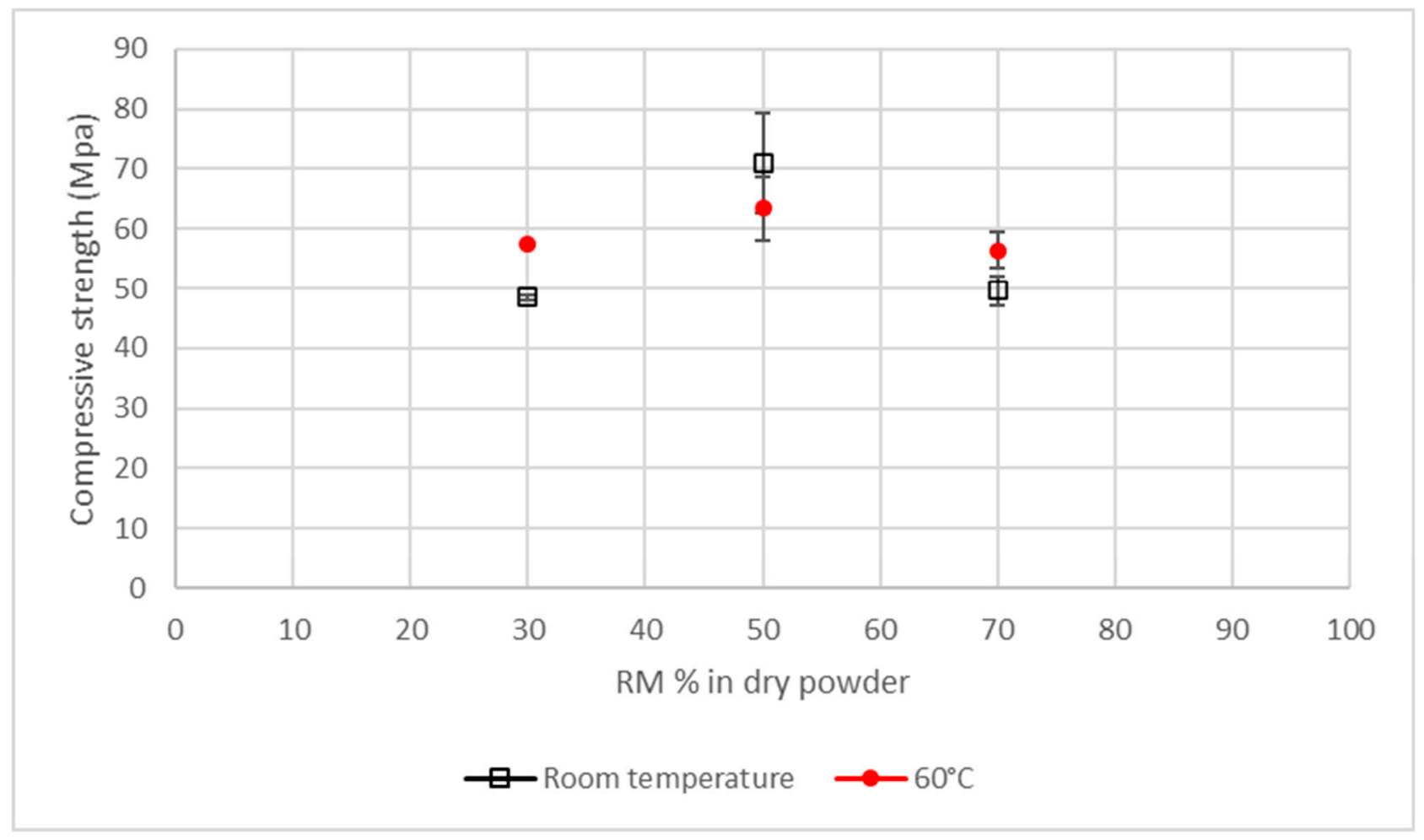

Figure 9. Compressive strength values for alkali-activated material obtained starting from RM, BFS, and alkaline solution with $\mathrm{R}=2$ and different percentages of RM in powder mix (30-70 wt.\%) molded in cubic $40 \mathrm{~mm}$ side samples. Hollow black squares: room temperature-cured samples; red circle: samples cured at $60{ }^{\circ} \mathrm{C}$ for $24 \mathrm{~h}$.

Using cubic shapes, the compressive strength increased by $85 \%$ on average, compared to cylindrical specimens. The compressive strength of samples cured at $60{ }^{\circ} \mathrm{C}$ showed similar values increasing the quantity of RM in the powder mixture, although, also in this case, the highest compressive strength was obtained for the sample with $50 \mathrm{wt} . \%$ of RM, cured at room temperature (with an average value of $72 \mathrm{MPa}$ ). The compressive strength values obtained are very interesting. In fact, using $70 \mathrm{wt} . \%$ of RM, the compressive strength was about $50 \mathrm{MPa}$ for all the samples (both curing at 25 to $60{ }^{\circ} \mathrm{C}$ ).

\section{Conclusions}

In this work, RM and BFS were tested as precursors for alkali-activated/geopolymer materials with SS solution. This is a preliminary study in which the percentages of precursors, activating solution basicity, curing temperature trends were obtained. The real applicability of bauxite residues from the Podgorica industrial site as a precursor of alkaliactivated materials was demonstrated. The sample prepared with the sole RM showed a strength value close to $12 \mathrm{MPa}$, but a small amount of BFS (20 wt.\% in powder mix) was sufficient to obtain values close to $30 \mathrm{MPa}$. The most significant results include the high compression strengths recorded for RM co-reacted with BFS in a 1 to 1 ratio, with $R=2$ and with values of about $45 \mathrm{MPa}$.

The compressive strength of cubic samples exceeded $50 \mathrm{MPa}$ with the higher values for pastes with $50 \mathrm{wt} . \%$ of RM in the powder mixture, cured at room temperature (average $72 \mathrm{MPa}$ ). These values are just slightly lower than in Lemougna [43], in which a starting RM with a sensibly lower percentage of iron was used, but strongly higher than samples prepared with the same RM and metakaolin in a previous work [32].

The blends studied in the present work could be a starting point for new RM-BFS based alkali-activated materials that could have broad applicability as alternative binders in mortars and concrete. A study on the possibilities of a scale-up of these new materials, the prospective validation and an evaluation of the environmental impact, with LCA 
analysis, of possible industrial productions as bricks, pavement blocks or precast units in the building industry are foreseen.

Author Contributions: Data curation, I.B., A.O.; funding acquisition, M.V. and C.F.; project administration, M.V.; supervision, C.F.; writing-review and editing, A.O., M.V., and C.F. All authors have read and agreed to the published version of the manuscript.

Funding: This study was funded by a grant from the Italian Ministry of Foreign Affairs and International Cooperation.

Institutional Review Board Statement: Not applicable.

Informed Consent Statement: Not applicable.

Data Availability Statement: Not applicable.

Acknowledgments: The authors thank Giovanni Morieri for assistance in analysis samples preparation and Luciana Cimino for performing IR analysis.

Conflicts of Interest: The authors declare that they have no known competing financial interests or personal relationships that could have appeared to influence the work reported in this paper.

\section{References}

1. World Aluminium. 2018. Available online: http://www.world-aluminium.org/statistics/alumina-production/ (accessed on 11 September 2020).

2. Totten, G.E.; MacKenzie, D.S. Handbook of Alluminium. In Physical Metallurgy and Process; CRC Press: New York, NY, USA, 2003.

3. Lima, M.S.S.; Thives, L.P.; Haritonovs, V.; Bajars, K. Red mud application in construction industry: Review of benefits and possibilities. In IOP Conference Series: Materials Science and Engineering; IOP Publishing: Riga, Latvia, 2017 ; Volume 251.

4. Hind, A.R.; Bhargava, S.K.; Grocott, S.C. The surface chemistry of Bayer process solids: A review. Colloids Surf. A Physicochem. Eng. Asp. 1999, 146, 359-374. [CrossRef]

5. Boskovic, I.V.; Nenadovic, S.S.; Kljajevic, L.M.; Vukanac, I.S.; Stankovic, N.G.; Lukovic, J.M.; Vukcevic, M.A. Radiological and physicochemical properties of red mud based geopolymers. Nucl. Technol. Radiat. Prot. 2018, 33, 188-194. [CrossRef]

6. Borra, C.R.; Blanpain, B.; Pontikes, Y.; Binnemans, K.; Van Gerven, T. Smelting of Bauxite Residue (Red Mud) in View of Iron and Selective Rare Earths Recovery. J. Sustain. Metall. 2016, 2, 28-37. [CrossRef]

7. The International Aluminium Institute. Primary Aluminium Production. 2016. Available online: http://www.world-aluminium. org/statistics (accessed on 11 September 2020).

8. Cardenia, C.; Balomenos, E.; Panias, D. Iron recovery from bauxite residue through reductive roasting process and wet magnetic separation. J. Sustain. Metall. 2018, 5, 9-19. [CrossRef]

9. Brown, T.J.; Idoine, N.E.; Raycraft, E.R.; Shaw, R.A.; Deady, E.A.; Hobbs, S.F.; Bide, T. World Mineral Production: 2013-2017; British Geological Survey: Notthingam, UK, 2019.

10. Stanford, K. Red Mud-Addressing the Problem. In Alluminium Insider. 2016. Available online: https://aluminiuminsider.com/ red-mud-addressing-the-problem/ (accessed on 11 September 2020).

11. Ayres, R.U.; Holmberg, J.; Andersson, B. Materials and the Global Environment: Waste Mining in the 21st Century. MRS Bull. 2001, 26, 477-480. [CrossRef]

12. Varnavas, S.; Ferentinos, G.; Collins, M. Dispersion of Bauxitic red mud in the Gulf of Corinth, Greece. Mar. Geol. 1986, 70, 211-222. [CrossRef]

13. Power, G.; Gräfe, M.; Klauber, C. Bauxite residue issues: I. Current management, disposal and storage practices. Hydrometallurgy 2011, 108, 33-45. [CrossRef]

14. Gelencser, A.; Kovats, N.; Turoczi, B.; Rostasi, A.; Hoffer, A.; Imre, K.; Nyiro-Kosa, I.; Csakberenyi-Malasics, D.; Toth, A.; Czitrovszky, A.; et al. The red mud accident in Ajka (Hungary): Characterization and potential health effect of fugitive dust. Environ. Sci. Technol. 2011, 45, 1608-1615. [CrossRef]

15. Clark, M.W.; McConchie, D.; Berry, J.; Caldicott, W.; Davies-McConchie, F.; Castro, J. Bauxsol technology to treat acid and metals; Applications in the coal industry. In Proceedings of the Joint Conference of the American Society of Mining and Reclamation and the 25th West Virginia Surface Mine Drainage Task Force, Morgantown, WV, USA, 18-22 April 2004; pp. $292-313$.

16. Smith, P.H.T. Recovery of Soda from Bauxite Residue. Australia Patent WO 2012/145797 Al, 27 April 2012.

17. World Aluminium. Available online: https://international-aluminium.org/resource/towards-sustainable-cities-series/ (accessed on 10 October 2021).

18. Jitsangiam, P.; Nikraz, H.; Jamieso, E. Pozzolanic-stabilised Mixture (PSM) for red sand as road base materials. In Proceedings of the 4th International Conference on Structural Engineering and Construction, Melbourne, Australia, 26-28 September 2007; pp. 647-651.

19. Klauber, C.; Gräfe, M.; Power, G. Bauxite residue issues: II. options for residue utilization. Hydrometallurgy 2011, 108, 11-32. [CrossRef] 
20. Tsakiridis, P.E.; Agatzini-Leonardou, S.; Oustadakis, P. Red mud addition in the raw meal for the production of Portland cement clinker. J. Hazard. Mater. 2004, 116, 103-110. [CrossRef]

21. Vangelatos, I.; Angelopoulos, G.N.; Boufounos, D. Utilization of ferroalumina as raw material in the production of Ordinary Portland Cement. J. Hazard. Mater. 2009, 168, 473-478. [CrossRef] [PubMed]

22. Huang, S.C.; Chang, F.C.; Lo, S.L.; Lee, M.L.; Wang, C.F.; Lin, J.D. Production of lightweight aggregates from mining residues, heavy metal sludge, and incinerator fly ash. J. Hazard. Mater. 2007, 144, 52-58. [CrossRef] [PubMed]

23. Nenadović, S.S.; Ferone, C.; Nenadović, M.T.; Cioffi, R.; Mirković, M.M.; Vukanac, I.; Kljajević, L.M. Chemical, physical and radiological evaluation of raw materials and geopolymers for building applications. J. Radioanal. Nucl. Chem. 2020, 325, 435-445. [CrossRef]

24. Capasso, I.; Liguori, B.; Ferone, C.; Caputo, D.; Cioffi, R. Strategies for the valorization of soil waste by geopolymer production: An overview. J. Clean. Prod. 2021, 288, 125646. [CrossRef]

25. Luukkonena, T.; Abdollahnejada, Z.; Yliniemia, J.; Kinnunena, P.; Illikainena, M. One-part alkali-activated materials: A review. Cem. Concr. Res. 2018, 103, 21-34. [CrossRef]

26. Frattini, D.; Occhicone, A.; Ferone, C.; Cioffi, R. Fibre-reinforced geopolymer concretes for sensible heat thermal energy storage: Simulations and environmental impact. Materials 2021, 14, 414. [CrossRef]

27. Roviello, G.; Ricciotti, L.; Molino, A.J.; Menna, C.; Ferone, C.; Asprone, D.; Cioffi, R.; Ferrandiz-Mas, V.; Russo, P.; Tarallo, O. Hybrid fly ash-based geopolymeric foams: Microstructural, thermal and mechanical properties. Materials 2020, $13,2919$. [CrossRef] [PubMed]

28. Roviello, G.; Ricciotti, L.; Molino, A.J.; Menna, C.; Ferone, C.; Cioffi, R.; Tarallo, O. Hybrid geopolymers from fly ash and polysiloxanes. Molecules 2019, 24, 3510. [CrossRef]

29. Ricciotti, L.; Occhicone, A.; Petrillo, A.; Ferone, C.; Cioffi, R.; Roviello, G. Geopolymer-based hybrid foams: Lightweight materials from a sustainable production process. J. Clean. Prod. 2020, 250, 119588. [CrossRef]

30. Liguori, B.; Aprea, P.; Roviello, G.; Ferone, C. Self-supporting zeolites by Geopolymer Gel Conversion (GGC). Microporous Mesoporous Mater. Vol. 2019, 286, 125-132. [CrossRef]

31. Schollbach, K.; van Hoek, C.; van der Laan, S.; de Wolf, T.; Brouwers, H.J.H. In-depth mineralogical quantification of MSWI bottom ash phases and their association with potentially toxic elements. Waste Manag. 2019, 87, 1-12.

32. Boskovic, I.; Vukcevic, M.; Nenadovic, S.; Mirkovic, M.; Stojmenovic, M.; Pavlovic, V.; Kljajevic, L. Characterization of Red Mud/Metakaolin-based geopolymers as modified by $\mathrm{Ca}(\mathrm{OH})_{2}$. Mater. Technol. 2019, 53, 341-348.

33. Roviello, G.; Chianese, E.; Ferone, C.; Ricciotti, L.; Roviello, V.; Cioffi, R.; Tarallo, O. Hybrid Geopolymeric Foams for the Removal of Metallic Ions from Aqueous Waste Solutions. Materials 2019, 12, 4091. [CrossRef] [PubMed]

34. Davidovits, J. Geopolymer Chemistry \& Applications, 3rd ed.; Joseph Davidovits: Saint-Quentin, France, 2011.

35. Hill, M.; Bastow, T.; Celotto, S.; Hill, A. Integrated Study of the Calcination Cycle from Gibbsite to Corundum. Chem. Mater. 2007, 19, 2877-2883. [CrossRef]

36. Gialanella, S.; Girardi, F.; Ischia, G.; Lonardelli, I.; Mattarelli, M.; Montagna, M. On the goethite to hematite phase transformation. J. Therm. Anal. Calorim. 2010, 102, 867-873. [CrossRef]

37. Atasoy, A. An investigation on characterization and thermal analysis of the Aughinish red mud. J. Therm. Anal. Calorim. 2015, 81, 357-361. [CrossRef]

38. Singha, S.; Aswathb, M.U.; Das Biswasb, R.; Ranganathc, R.V.; Choudharyd, H.K.; Kumard, R.; Sahoo, B. Role of iron in the enhanced reactivity of pulverized Red mud: Analysis by Mössbauer spectroscopy and FTIR spectroscopy. Case Stud. Constr. Mater. 2019, 11, e00266.

39. Barbosa, V.F.F.; Mackenzie, K.J.D.; Thaumaturgo, C. Syntesis and characterization of materials based on inorganic polymers of alumina and silica: Sodium polysialate polymers. Int. J. Inorg. Mater. 2000, 2, 309-317. [CrossRef]

40. Roviello, G.; Ricciotti, L.; Ferone, C.; Colangelo, F.; Cioffi, R.; Tarallo, O. Synthesis and Characterization of Novel Epoxy Geopolymer Hybrid Composites. Materials 2013, 6, 3943-3962. [CrossRef]

41. Mirzaei, A.; Janghorban, K.; Hashemi, B.; Hosseini, S.R.; Bonyani, M.; Leonardi, S.G.; Bonavita, A.; Neri, G. Synthesis and characterization of mesoporous $\alpha-\mathrm{Fe}_{2} \mathrm{O}_{3}$ and investigation of electrical properties of fabricated thick films. Process. Appl. Ceram. 2016, 10, 209-217. [CrossRef]

42. Davidovits, J. Geopolymer Chemistry \& Applications; Institut-Géopolymér: Saint-Quentin, France, 2008.

43. Lemougna, P.N.; Wang, K.; Tang, Q.; Cui, X. Study on the development of inorganic polymers from red mud and slag system: Application in mortar and lightweight materials. Constr. Build. Mater. 2017, 156, 486-495. [CrossRef]

44. Zivica, V. Effects of type and dosage of alkaline activator and temperature on the properties of alkali-activated slag mixtures. Constr. Build. Mater. 2007, 21, 1463-1469. [CrossRef] 